\title{
Globalization processes in the modern world challenging the national economy development
}

\author{
Alla Kasych $^{1, *}$, and Marek Vochozka ${ }^{2}$ \\ ${ }^{1}$ Kyiv National University of Technologies and Design, Management Department, Kyiv, Ukraine \\ ${ }^{2}$ Institute of Technology and Business in České Budějovice, České Budějovice, Czech Republic
}

\begin{abstract}
The article studies theoretical, methodological and analytical aspects of the globalization processes development, which increasingly affect the economic dynamics of a particular country. Synthesis of scientific approaches by leading scientists allows establishing the key characteristics and forms of globalization. The authors highlight ecological and cultural globalization, which increasingly affect economic processes. Analytical studies have been conducted in the context of establishing and substantiating maj or challenges that are increasingly complex and large-scale. Thus, the nature of the challenges is identified in terms of opportunities and threats to the development of the national economy. This article identifies a possible list of globalisation challenges through their actions as opportunities or threats. Substantiated by the authors the key development trends of globalization evidences of its versatility, multi-vectoral focus and interdependence of forms. The authors suggest the key measures for responding to the challenges of the "catching-up" economy globalization.
\end{abstract}

\section{Introduction}

Globalization has become the most large-scale and dynamic process in modern conditions because of which the global economy acquires common and unified features. Accordingly, the identification of globalized economy characteristics is important since it allows not only to identify current trends in the development but also to provide understanding of promising changes that may pose a threat to the development of individual countries in the near future.

According to the National Intelligence Council [1], the key trends in the development of the globalized world by 2035 will be the weak economic growth and thus, the main economies will face a reduction in labour force and a decrease in productivity growth; accelerating technological progress that will create new opportunities, but will lead to increased discrepancies between leaders and outsiders; the further spread of automation and artificial intelligence, which threaten to swiftly change the industry, potentially pushing workers with traditional skills and limiting the usual development path for poor countries; climate change, environmental and health problems that will require more attention and collective action, even if cooperation becomes more difficult; the change in the nature of conflicts, the number of which will increase because of divergent interests among the great powers, the expansion of terrorist threats.

The versatility and dynamics of the world economy development point to the need for a systematic study of the globalization processes in order to identify those challenges to which countries have to react already at the current time, because their neglect will only lead to further deviations from the trends.

In view of the importance of global economy challenges, scientists are constantly exploring them. The works by J. Ocampo [2], V. Gunter and R. Hoeven [3], L. Movius [4], R. Robertson [5], and others are among the most significant. Ukrainian scientists, in particular O. Bilorus [6], V. Geets [7-9], A. Filippenko [10], have also joined the process of studying the globalization processes.

Ukrainian scientists, in particular O. Bilorus [6], V. Geets [7-9], A. Filippenko [10], have also joined the process of studying the globalization processes.

Without trying to generalize all existing definitions of the concept of "globalization", which are presented in the scientific literature, we will focus on those that reflect the nature of the investigated processes and allow distinguishing the key essential characteristics to the greatest extent (Table 1).

Globalization as a phenomenon means that there is an increase in the interaction and interdependence between different countries and regions of the world in the field of economy, politics, and culture. Considering globalization figuratively, it can be argued that this is the process of forming an infinite world, when state borders turn into formalities on the path of displaced both factors and results of processes of human management of the mankind.

The International Monetary Fund Experts [19], by focusing on the economic nature of the phenomenon under investigation, characterize globalization as a growing economic interdependence of countries around the world through an increase in the international

\footnotetext{
* Corresponding author: kasich.alla@gmail.com
} 
exchange of goods, services, capital, technologies, knowledge, ideas and labour force.

Table 1. The key essential characteristics of the concept of "globalization".

\begin{tabular}{|c|c|c|}
\hline Author & Essence & $\begin{array}{c}\text { Key } \\
\text { characteristic }\end{array}$ \\
\hline $\begin{array}{ll}\text { T. } & \text { Levitt } \\
{[11]} & \end{array}$ & $\begin{array}{l}\text { Globalized markets are world } \\
\text { markets for standardized consumer } \\
\text { products. In the process of global } \\
\text { homogenization, modern markets } \\
\text { are expanding to achieve cost } \\
\text { savings on a global scale. }\end{array}$ & $\begin{array}{l}\text { The } \\
\text { emergence of } \\
\text { global } \\
\text { markets }\end{array}$ \\
\hline $\begin{array}{l}\text { R. F. Nayef } \\
{[12]}\end{array}$ & $\begin{array}{l}\text { Globalization is a process that } \\
\text { covers the causes, course and effects } \\
\text { of transnational and transcultural } \\
\text { integration within human activities }\end{array}$ & $\begin{array}{l}\text { Causal and } \\
\text { consequential } \\
\text { nature }\end{array}$ \\
\hline $\begin{array}{l}\text { S. Fischer } \\
{[13]}\end{array}$ & $\begin{array}{l}\text { Globalization is a continuous } \\
\text { process of growing interdependence } \\
\text { between countries and their citizens }\end{array}$ & $\begin{array}{l}\text { Continuity of } \\
\text { processes }\end{array}$ \\
\hline \begin{tabular}{|l} 
Z. Bauman \\
{$[14$, p. 35] }
\end{tabular} & $\begin{array}{l}\text { It is an uncertain, uncontrollable and } \\
\text { independent character of everything } \\
\text { happening in the world; absence of } \\
\text { a remote control, management, } \\
\text { board of directors or head office. It } \\
\text { is just another name for the world } \\
\text { "disorder" }\end{array}$ & $\begin{array}{l}\text { Inertia and } \\
\text { uncertainty } \\
\text { of processes }\end{array}$ \\
\hline $\begin{array}{l}\text { S. Kay [15, } \\
\text { p. 10] }\end{array}$ & $\begin{array}{l}\text { Globalization is a process of } \\
\text { promoting a new ideal of economic } \\
\text { openness, political transparency and } \\
\text { global culture. }\end{array}$ & $\begin{array}{l}\text { Spread of } \\
\text { basic values } \\
\text { of society }\end{array}$ \\
\hline \begin{tabular}{|l|} 
S. Reich \\
{$[16]$}
\end{tabular} & $\begin{array}{l}\text { Globalization is an interconnected } \\
\text { set of economic phenomena. These } \\
\text { include liberalization and } \\
\text { deregulation of markets, asset } \\
\text { privatization, waivers of state } \\
\text { functions, technology spread, } \\
\text { international distribution of } \\
\text { production, and the integration of } \\
\text { capital markets }\end{array}$ & $\begin{array}{l}\text { The complex } \\
\text { nature of } \\
\text { economic } \\
\text { processes }\end{array}$ \\
\hline $\begin{array}{l}\text { C. Thomas } \\
{[17]}\end{array}$ & $\begin{array}{l}\text { Globalization is a process whereby } \\
\text { the power is in global social } \\
\text { formations and is expressed through } \\
\text { global networks, and not through } \\
\text { territorially based states }\end{array}$ & $\begin{array}{l}\text { Reducing the } \\
\text { role of state } \\
\text { borders }\end{array}$ \\
\hline \begin{tabular}{|l|} 
I. Clark \\
{$[18$, p. 494] }
\end{tabular} & $\begin{array}{l}\text { Globalization is a transformation in } \\
\text { relations between states, but at the } \\
\text { same time, it is a transformation of } \\
\text { the nature of the state itself }\end{array}$ & $\begin{array}{l}\text { Changing } \\
\text { interstate } \\
\text { relations and } \\
\text { internal } \\
\text { processes in } \\
\text { the state }\end{array}$ \\
\hline
\end{tabular}

Thus, globalization as a process of unifying socioeconomic and political processes in its development raises new challenges for individual countries. Other forms of globalization affect even those countries that are less globalized economically, and therefore their successful development depends largely on the ability to respond adequately to constantly emerging challenges.

\section{Existing methods and dynamics}

To measure globalization in 2002, the Swiss Institute of Economics [20] proposed a methodology for calculating the KOF globalization index, which is a combined indicator of economic, political and social globalization (Fig. 1).

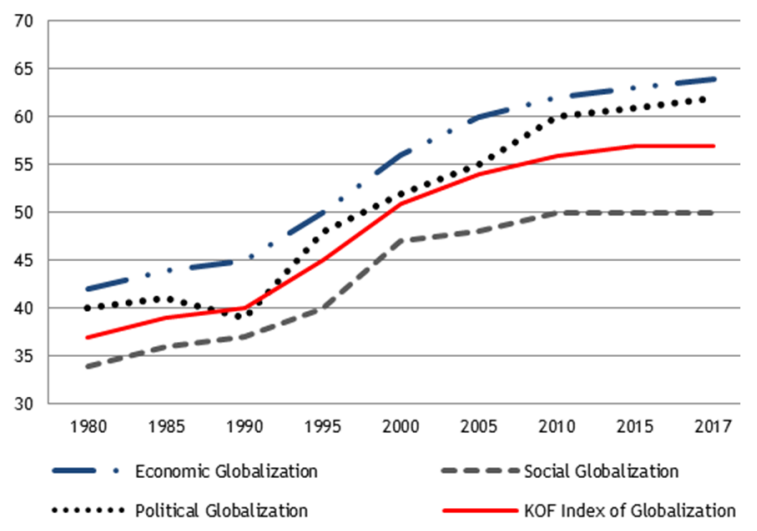

Fig. 1. The dynamics of the Globalization Index and its components. Source: [20]

The Globalization Index is calculated as the sum of these components with a weighting of $36 \%, 39 \%$ and $25 \%$, respectively.

The specialized databases of the World Bank, the International Monetary Fund, the United Nations, the International Telecommunication Union, other international organizations and statistical institutes are the information sources in the development of the Index.

The dynamics of globalization and its constituents testifies to the irreversibility of mutual influence and increasing the level of synchronization of the processes of functioning of an increasing number of countries in the world. The greatest progress has taken place at the level of economic globalization. Political globalization also progressed, but social globalization was characterized by stagnation. According to the KOF Globalization Index for 2017, the Netherlands - 92.84, Ireland - 92.15 and Belgium - 91.75 were the most globalized. Globalization as a process of unifying socio-economic and political processes in its development raises new challenges for individual countries. Other forms of globalization affect even those countries that are less globalized economically, and therefore their successful development depends largely on the ability to respond adequately to constantly emerging challenges.

To identify the economic globalization' regularities will be used such methods as analysis, synthesis, graphic, and others.

\section{Results}

\subsection{Forms of globalization}

In general, the globalization processes have become an objective reality of the modern stage of the world development. The complexity their shapes has taken place gradually: if in the initial stages it concerned the functioning of the global markets for goods, services and the unification of requirements for production, the spread of globalization to other spheres of human life: social, technological, and cultural takes place in today's conditions. 
The deepening of the globalization processes leads to the emergence of a system of mutually supporting causeeffect relationships between its forms. That is why globalization should be seen as a complex multi-faceted phenomenon. The substantive characteristics of individual forms of globalization in their modern sense are presented in Fig. 2.

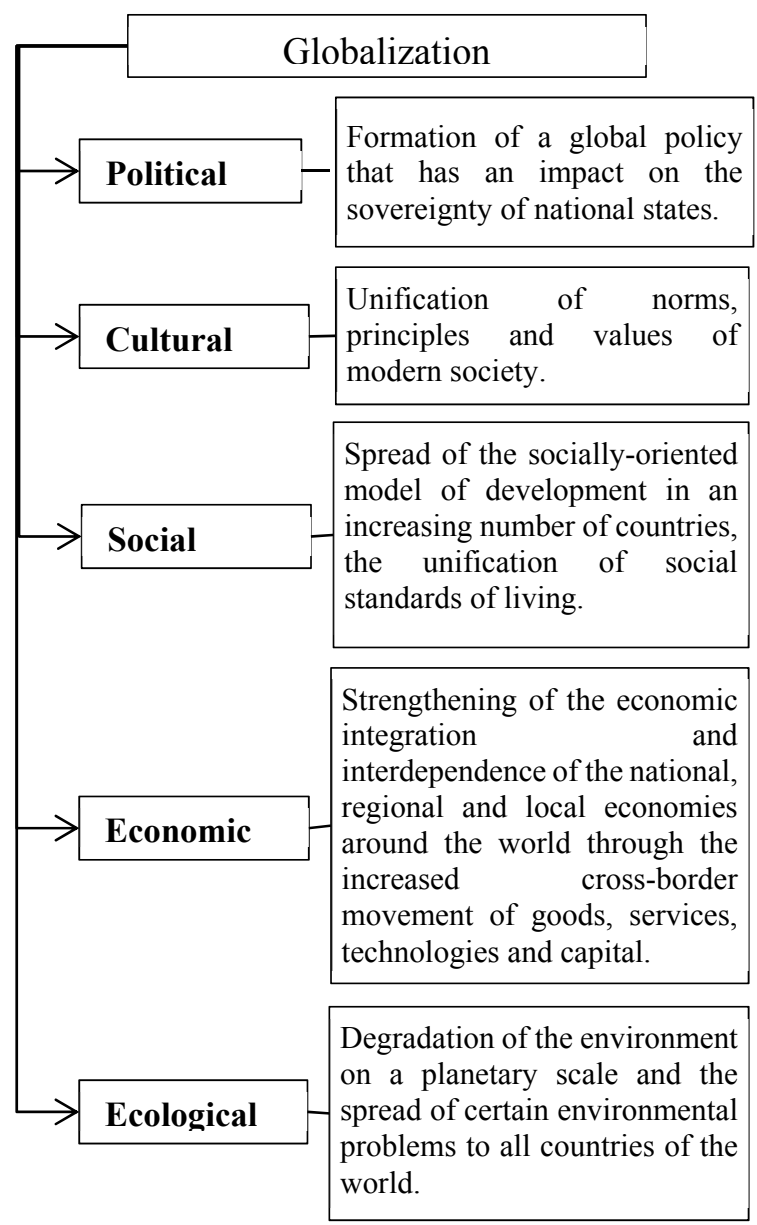

Fig. 2. The main forms of globalization.

The openness of socio-economic systems leads to the fact that under the influence of globalization processes, there had been the harmonization of functioning processes of the world economy within an increasing number of forms, from ecological and economic to social and cultural. The integrated nature of globalization is manifested in the fact that the country's involvement in the processes of globalization within certain forms leads to a phased expansion among others. That is, globalization, on the one hand, ensures the unification of the working conditions for all countries of the world, and, on the other hand, creates challenges, ignoring of which leads to fragmentation of the development in separate countries of the world. Conversely, if the country is using the "new" achievements of world civilization, then as a result, it is involved (drawn) into the processes of globalization that ensures their transformation into the drivers of internal modernization.

The objective nature of the globalization processes determines the need to take into account their content, trends, quantitative and qualitative characteristics in all forms, which in aggregate can be attributed to the challenges facing certain countries. Challenges are factors behind the overall action, which are connected with the appearance of new ideas, processes, transformations in any field of human life, the discrepancy that leads to the emergence of threats, and compliance - opens opportunities for further development. The identification of threats, as well as understanding of opportunities, determines the country's ability to use the situation in the context of providing development, primarily internal subsystems.

\subsection{Globalization challenges of the national economy development}

The challenges of globalization should be considered in terms of political, economic, social, demographic and environmental kinds.

1. There are growing doubts about the indispensability of the "western" democratic model of development based on the laws of the market economy and the protection of private property. The global trend of the past decades of the world's transition to democracy has not only slowed down, but also, according to experts from The Economist, has the opposite trend.

Development dynamics, primarily of China, questioned about the significance of democracy as a condition for economic development. The Democratization Index, which takes into account the electoral process and pluralism, civil liberties, the functioning of power, political participation and political culture, according to The Economist [21], shows the worst downturn in global democracy since the financial crisis of 2010-11, when freedom of expression looks of particular concern. However, in our opinion, even the existing "rollback" of democracy is temporary, since the understanding that the innovative activity, on which economic development depends, most effectively manifests itself in the conditions of a prevailing market economy, will ensure further spread of the democracy principles.

2. Aggravation of global competition. There is not only an aggravation of the global competition between countries, enterprises, and its transfer to the dependence on the development of "high" factors, which are a serious barrier to other participants joining these processes. Leadership tussle does not stop at any level of the world economy functioning. The competition for leadership within particular regions, pretensions to global leadership - all of this leads to the search for real competitive advantages, which increasingly depend on the quality of the established socio-economic system in those or other countries. In fact, it can be argued that the targeting of powerful players to provide the competitive advantages by every means has become an additional factor in the globalization processes.

3. The economic basis of globalization is a challenge for any country, as it manifests itself in synchronizing the dynamics of economic development (GDP). Proof of this is the fact that the latest economic crisis has gone beyond 
the region or the group of countries and has fully acquired signs of a global one.

Studies by IMF experts [22] indicate that economic dynamics in some countries are largely affected by the development in others. Thus, the temporary slowdown in the US growth rate about 1 percentage point directly leads to a decline in growth in all European countries by about 0.5 percent. In addition, indirect secondary effects of lowering growth rates in the developed European countries may weaken growth in emerging markets by 0.25 percent.

Secondary effects can also be manifested in employment: the reduction of the employed population in the developed countries leads to a reduction in the employment in the countries with emerging markets, as it is precisely in these countries that a number of assembly plants of TNCs are located. On the other hand, the slowdown in the dynamics of China development leads to a slowdown in global GDP.

Thus, a higher level of openness of the economy in the developing countries for trade, financial and other flows makes these countries more vulnerable to secondary effects caused by events in the global economy and requires the formation of a powerful internal market that can support certain dynamics of economic development.

4. The achieved level of economic development of certain countries, and the gaps, which are only increasing. The effect of the achieved level of development has a powerful impact, since it is the size of GDP, including per capita, determines the country's ability to form the resource needed for further development. An increasing proportion of the countries are following upon the path of reforms for ensuring welfare and raising incomes, as a result, the average GDP per capita rate is gradually increasing, and in the period from 1990 to 2016, it increased by 2.4 times (Fig. 3).

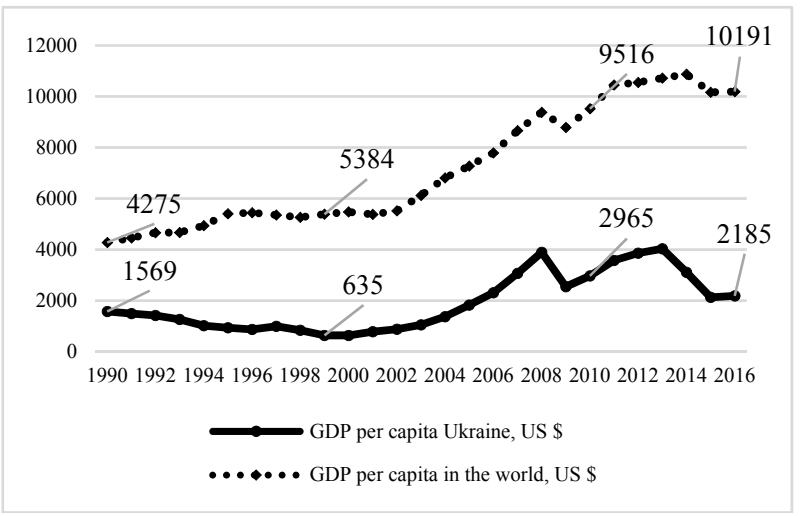

Fig. 3. Dynamics of GDP per capita in the world and Ukraine, \$ USA Source: constructed by the authors according to [23].

The indicators presented in Fig. 3 and the example of Ukraine used for comparison show not only the lagging behind the average values, but its increase over the last 27 years (in 1990 it was 2.7 times, and in 2016-4.7). This state of affairs shows that our country remains at the periphery of the world economy, and the challenge for our country is to adhere to stable, albeit small, GDP growth. In order to ensure at least an average GDP per capita in the world, it is necessary that the rate of growth of
Ukraine's GDP significantly exceed the dynamics of the corresponding indicator in the world.

5. The international trade relationships, which are the embodiment of the globalization processes, have been actively developing over the past 30 years, as evidenced, first, by the volumes of the exports of goods and services.

International trade is an important factor in the development of the world economy, in so doing the growth of exports over the past decades has been more dynamic than GDP growth. Over the past three decades, the world exports of goods and services have increased by about 10.3 times, while GDP is 3.5 times higher. As a result, the globalization level of the world markets has increased, the confirmation of which was the share of exports of goods and services in the world GDP, which stood at $18.9 \%$ in 1980 , and in 2016 , it increased to $28.6 \%$. In fact, one third of world GDP is realized on the global markets.

Despite the fact that services represent an increasing share in the GDP structure of the selected countries and the world GDP, the role of goods exports in the global market is unquestionable. International trade in services is also increasing, but considering the specifics of its own services, it plays a much smaller role.

The average annual growth rate of the international trade in goods during the period under study amounts $16 \%$ against the background of $17 \%$ - the growth rate of international trade in services. A higher growth rate of the exports of services has led to some structural changes in the total exports: services accounted for $17.8 \%$ in 1985 , and in 2015 , they rose to $21 \%$.

The market globalization of more and more goods is an important challenge for manufacturers in all countries of the world, since requirements harmonization deals with not only quantitative and qualitative characteristics of products, but also technical and technological characteristics of the production. Those businesses and countries that are not able to meet the requirements of the globalized markets cannot use its advantages and are pushed out.

6. Quantitative and qualitative characteristics of the investment-innovative activity, which is the most important driver of economic development in modern conditions, is a powerful challenge that requires the implementation of a long-term strategy and complex conditions for strengthening. The achieved level of the development of investment-innovative activity, reached by countries-leaders, is the result of a long-term channelling of the created benefit for investment and innovation.

The level of investment activity of the global economy (in terms of the share of GDP) is at $23-27 \%$ with a certain decline from 2000 to 2017 (table 2).

Significantly, this indicator depends on the assignment of the countries to the developed or the developing countries, and showing a relative decline in the investment activity in the countries that have reached a certain level of development. Indicator of the share of investment in GDP can be used to determine the period of the active capital accumulation. In the selected periods in some countries, this figure is up to the level of $30-48 \%$. This means that investing in the fixed assets and in 
knowledge, that is, in modernization, is actually the prior direction of the use of the created GDP.

Table 2. Indicators of the investment activity of individual countries of the world.

\begin{tabular}{|c|c|c|c|c|c|c|}
\hline \multirow[t]{2}{*}{ Countries } & \multicolumn{3}{|c|}{$\begin{array}{c}\text { Share of investments in } \\
\text { GDP, \% }\end{array}$} & \multicolumn{3}{|c|}{$\begin{array}{c}\text { Investment, US \$ per } \\
\text { capita }\end{array}$} \\
\hline & 2000 & 2010 & 2017 & 2000 & 2010 & 2017 \\
\hline World & 24.1 & 23.9 & 24.2 & 1315 & 2266 & 2601 \\
\hline \multicolumn{7}{|c|}{ Developed countries } \\
\hline USA & 21 & 15 & 21 & 7654 & 7256 & 11204 \\
\hline Germany & 24 & 19 & 20 & 5692 & 7939 & 9394 \\
\hline France & 20 & 19 & 23 & 4495 & 7733 & 9852 \\
\hline Japan & 25 & 20 & 24 & 9633 & 8900 & 11656 \\
\hline Sweden & 22 & 23 & 26 & 6442 & 11977 & 14718 \\
\hline \multicolumn{7}{|c|}{ Developing countries } \\
\hline Korea & 31 & 30 & 31 & 3700 & 6645 & 8107 \\
\hline India & 24 & 36 & 31 & 108 & 484 & 615 \\
\hline China & 35 & 48 & 44 & 335 & 2188 & 3225 \\
\hline Brazil & 18 & 20 & 15 & 670 & 2224 & 1637 \\
\hline Mexico & 22 & 22 & 23 & 1460 & 1950 & 2286 \\
\hline Turkey & 20 & 19 & 31 & 843 & 1920 & 4630 \\
\hline \multicolumn{7}{|c|}{ Transitive economics } \\
\hline Poland & 25 & 21 & 20 & 1123 & 2645 & 3165 \\
\hline Czechia & 31 & 27 & 26 & 1860 & 5536 & 5916 \\
\hline Russia & 19 & 23 & 24 & 337 & 2455 & 2748 \\
\hline Ukraine & 20 & 20 & 21 & 127 & 593 & 629 \\
\hline
\end{tabular}

Source: constructed by the authors according to [23].

The same disproportions are taking place in terms of R\&D investment (table 3).

Table 3. Indicators of the innovative activity of individual countries of the world.

\begin{tabular}{|c|c|c|c|c|c|c|}
\hline \multirow[t]{2}{*}{ Countries } & \multicolumn{3}{|c|}{$\begin{array}{c}\text { Research and } \\
\text { development } \\
\text { expenditure, \% of } \\
\text { GDP }\end{array}$} & \multicolumn{3}{|c|}{$\begin{array}{l}\text { Research and deve- } \\
\text { lopment expenditure, US } \\
\text { \$ per capita }\end{array}$} \\
\hline & 2000 & 2010 & 2016 & 2000 & 2010 & 2016 \\
\hline World & 2.06 & 2.04 & 2.23 & 163 & 262 & 350 \\
\hline \multicolumn{7}{|c|}{ Developed countries } \\
\hline USA & 2.62 & 2.73 & 2.74 & 955 & 1320 & 1461 \\
\hline Germany & 2.39 & 2.71 & 2.89 & 652 & 1064 & 1362 \\
\hline France & 2.08 & 2.17 & 2.24 & 545 & 782 & 959 \\
\hline Japan & 2.90 & 3.14 & 3.12 & 770 & 1099 & 1335 \\
\hline Sweden & - & 3.22 & 3.26 & - & 1342 & 1845 \\
\hline \multicolumn{7}{|c|}{ Developing countries } \\
\hline Korea & 2.18 & 3.45 & 4.23 & 394 & 1048 & 1098 \\
\hline India & 0.74 & 0.82 & 0.83 & 15 & 35 & 39 \\
\hline China & 9.89 & 1.71 & 2.07 & 26 & 160 & 154 \\
\hline Brazil & 1.00 & 1.16 & 1.31 & 90 & 165 & 142 \\
\hline Mexico & 0.32 & 0.54 & 0.49 & 33 & 79 & 98 \\
\hline Turkey & 0.48 & 0.84 & 0.88 & 46 & 146 & 131 \\
\hline \multicolumn{7}{|c|}{ Transitive economics } \\
\hline Poland & 0.64 & 0.72 & 0.97 & 68 & 152 & 157 \\
\hline Czechia & 1.12 & 1.34 & 1.73 & 181 & 371 & 368 \\
\hline Russia & 1.05 & 1.13 & 1.11 & 72 & 232 & 126 \\
\hline Ukraine & 0.96 & 0.83 & 0.45 & 36 & 64 & 33 \\
\hline
\end{tabular}

Source: constructed by the authors according to [23].
As a result, the innovation sector in developed countries receives investments in several times more, including per capita.

The inability of the selected countries to generate the necessary amount of investment limits their innovative activity and leads to technological discontinuities and growing economic backlog.

Structural changes in the direction of accelerated development of promising sectors of the economy are the result of high investment and innovation activity in the country. That is, the economic growth of the leading countries is due to the introduction of innovations into the traditional sectors of the economy and their modernization, as well as through the formation of new sectors that provide qualitative characteristics of economic growth. Accordingly, there is a search for the sectors of the economy that can provide the developed countries with higher growth rates. The mechanism of enhancement of innovation is presented in the work [24].

7. In the globalization conditions, the demographic challenges have become more meaningful, they manifest themselves in the uneven dynamics of the population growth, the intensification of migration processes, the differentiation of countries by income level, the unification of labour requirements, etc. Demographic challenges are a powerful driver for development, but also a serious threat to the further development of a large number of countries.

Rapid growth of the population, for example in China, has transformed this country into a labour-intensive economy and, of course, has provided competitive advantages on the world market at the expense of the fact that labour is cheap enough. This factor has become one of the most important for the country's economic growth and a challenge for other countries.

In addition, the impact of globalization on the development of the labour market is manifested in the balancing supply and demand through the international migration. Thus, the number of international migrants was 82 million people in 1970 and 257 million people in 2017 [25]. That is, over the past 47 years, the number of international migrants increased by 3.1 times, while the growth of trade and capital turnover was more dynamic. At the same time, the share of international migrants over the past decade as a whole did not exceed $3 \%$ of the total world population.

On the other hand, the role of international migration to certain countries of the world is quite significant, as due to international migration, there is a replenishment of the necessary categories of labour and ensured the receipt of currency in the country. Negative, however, is that the excessive emigration can lead to a loss of human resources in the country, what is emphasized in the work [26].

As is the case with competition within demographic factors, globalization determines synchronization, including at the level of high parameters. Thus, new workplaces created around the world require professionals with the best knowledge and skills that contributes to the qualitative growth of labour in more and more countries. That means that in many cases, foreign migrants who have not been able to realize themselves in 
the home countries of origin in the host countries plays a prominent role.

Table 4. Globalization challenges as opportunities and threats to the country's development.

\begin{tabular}{|c|c|c|}
\hline \begin{tabular}{|c|} 
Types \\
of \\
Glo- \\
bali- \\
zation
\end{tabular} & $\begin{array}{c}\text { Challenges that open up } \\
\text { opportunities }\end{array}$ & $\begin{array}{c}\text { Challenges that are } \\
\text { threats }\end{array}$ \\
\hline \multirow{3}{*}{$\begin{array}{c}\text { Politi- } \\
\text { cal }\end{array}$} & $\begin{array}{l}\text { The spread of liberal valu- } \\
\text { es and democratic forms } \\
\text { of political system of the } \\
\text { countries of the world. }\end{array}$ & $\begin{array}{l}\text { Reducing the role of inter- } \\
\text { national organizations. }\end{array}$ \\
\hline & \multirow{2}{*}{$\begin{array}{l}\text { Creating a strong network } \\
\text { of regional and global ins- } \\
\text { titutions as the basis for } \\
\text { building a better interna- } \\
\text { tional order. }\end{array}$} & $\begin{array}{l}\text { Uneven actions of global } \\
\text { processes participants. }\end{array}$ \\
\hline & & $\begin{array}{l}\text { The spread of terrorist thre- } \\
\text { ats. }\end{array}$ \\
\hline \multirow{3}{*}{$\begin{array}{l}\text { Cul- } \\
\text { tural }\end{array}$} & $\begin{array}{l}\text { Distribution of the prin- } \\
\text { ciples of multiculturalism. }\end{array}$ & $\begin{array}{l}\text { Homogenization of crops } \\
\text { and loss of national identity. }\end{array}$ \\
\hline & $\begin{array}{l}\text { Development of anthropo- } \\
\text { cosmic culture. }\end{array}$ & $\begin{array}{l}\text { Development of technica- } \\
\text { lism. }\end{array}$ \\
\hline & $\begin{array}{l}\text { Mutual enrichment of dif- } \\
\text { ferent national cultures } \\
\text { through access to others. }\end{array}$ & $\begin{array}{l}\text { Reducing the importance of } \\
\text { the principles of universal } \\
\text { values priority. }\end{array}$ \\
\hline \multirow{4}{*}{ Social } & $\begin{array}{l}\text { Ensuring and improving } \\
\text { social protection. }\end{array}$ & $\begin{array}{l}\text { Preserving the growing na- } \\
\text { tional inequality. }\end{array}$ \\
\hline & $\begin{array}{l}\text { The growth of the signifi- } \\
\text { cance of the humanitarian } \\
\text { sphere and the role of in- } \\
\text { tellectual capital. }\end{array}$ & International migration. \\
\hline & $\begin{array}{l}\text { Adoption of basic labour } \\
\text { standards. }\end{array}$ & \multirow{2}{*}{$\begin{array}{l}\text { Migration of intellectual and } \\
\text { proactive workforce. }\end{array}$} \\
\hline & $\begin{array}{l}\text { Formation of information } \\
\text { society. }\end{array}$ & \\
\hline \multirow{4}{*}{$\begin{array}{c}\text { Eco- } \\
\text { nomic }\end{array}$} & $\begin{array}{l}\text { Aggravating competition } \\
\text { and its transition to ano- } \\
\text { ther, higher level. }\end{array}$ & $\begin{array}{l}\text { Synchronizing the dynamics } \\
\text { of economic development } \\
\text { and increasing vulnerabili- } \\
\text { ty, especially developing } \\
\text { countries, to external } \\
\text { shocks. }\end{array}$ \\
\hline & $\begin{array}{l}\text { Attract resources that the } \\
\text { system is incapable of } \\
\text { working out. }\end{array}$ & $\begin{array}{l}\text { Maintaining and increasing } \\
\text { the asymmetry of economic } \\
\text { and technological develop- } \\
\text { ment. }\end{array}$ \\
\hline & $\begin{array}{l}\text { The spread of the market } \\
\text { economy to an increasing } \\
\text { number of countries. }\end{array}$ & $\begin{array}{l}\text { A high and constant concen- } \\
\text { tration of technological } \\
\text { progress in industrialized } \\
\text { countries that continue to } \\
\text { maintain their hegemony. }\end{array}$ \\
\hline & $\begin{array}{l}\text { New Industrial Revoluti- } \\
\text { on. }\end{array}$ & $\begin{array}{l}\text { The inability of the develo- } \\
\text { ping countries to join the in- } \\
\text { ternational division of labo- } \\
\text { ur. }\end{array}$ \\
\hline \multirow{3}{*}{$\begin{array}{l}\text { Eco- } \\
\text { logi- } \\
\text { cal }\end{array}$} & $\begin{array}{l}\text { Changing the guidelines } \\
\text { for state policy on compli- } \\
\text { ance with environmental } \\
\text { norms. }\end{array}$ & $\begin{array}{l}\text { Transfer of environmentally } \\
\text { hazardous production to the } \\
\text { territory of backward coun- } \\
\text { tries. }\end{array}$ \\
\hline & $\begin{array}{l}\text { Reducing the environmen- } \\
\text { tal burden on the environ- } \\
\text { ment. }\end{array}$ & $\begin{array}{l}\text { Complication of conditions } \\
\text { for economic activity. }\end{array}$ \\
\hline & $\begin{array}{l}\begin{array}{l}\text { The development of alter- } \\
\text { native energy. }\end{array} \\
\end{array}$ & $\begin{array}{l}\text { Increased costs of comply- } \\
\text { ing with environmental } \\
\text { standards. }\end{array}$ \\
\hline
\end{tabular}

Summarizing the above-mentioned, it is advisable to allocate a possible list of challenges through their actions as opportunities or threats (table 4).

\section{Conclusions}

During the examination the globalization processes such key characteristics should be taken into account: - cause-effect character, which means proliferation of manifestations of unification and synchronization into an ever-increasing number of society life spheres;

- continuity means that the dynamics of globalization in one or another manifestation happens all the time, this is due to the action of general principles dialects that determine the interactions of its individual chains;

- uncontrollability and uncertainty testify to the inability of any institutions and systems to provide regulation and adjustment of processes in the required direction.

In general, the study of the globalization processes allows:

- firstly, to outline the functional areas that require constant monitoring in the process of adapting the national economy to the objective processes taking place in the modern world;

- secondly, to determine the quantitative indicators of the globalization processes, which allows to determine the target orientation of the country's development;

- thirdly, to systematize specific challenges that threaten the development of an individual country and open up opportunities for it.

In considering the "catching-up" development model as a systematic response to globalization challenges, we should underline the importance of modernizing the economy through industrialization of the industrial sector and ensuring a gradual transition to a post-industrial economy, directing the development of education and science to strategic modernization objectives; modernizing society by raising the level of democratization and cultural and educational level of the population of the country; modernization of relations as the basic principle of functioning and formation of market relations, which will provide modernization of demand and supply both for finished products and for production factors.

\section{References}

1. Global trends: paradox of progress. A publication of the National Intelligence Council http://www.dni.gov/nic/globaltrends (2017). Accessed 28 Nov 2018

2. Ocampo, J.: Rethinking Global Economic and Social Governance. Journal of Globalization and Development. 1(1) (2010). doi:10.2202/19481837.1020

3. Gunter, B., Hoeven, R.: The social dimension of globalization. A review of the literature. International Labour Review. 143(1-2), 7-43 (2004). doi:10.1111/j.1564-913X.2004.tb00545.X 
4. Movius, L.: Cultural Globalisation and Challenges to Traditional Communication Theories. Journal of Media and Communication. 2(1), 6-18 (2010)

5. Featherstone, M., Lash, S., Robertson, R.: Glocalization: Time-Space and HomogeneityHeterogeneity. In: Featherstone, M., Lash, S., Robertson, R. (eds.) Global Modernities, pp. 25-44. SAGE, New York (1995). doi:10.4135/9781446250563.n2

6. Bilorus, O.: Globalization and development security. KNEU, Kyiv (2001)

7. Geets, V., Grycenko, A.: Economics and Society: Unrecognizable Faces of Interaction. Economics of Ukraine. 6, 4-19 (2013)

8. Geets, V.: Liberal-democratic foundations: a course on modernization of Ukraine. Economics of Ukraine. 3, 4-20 (2010)

9. Geets, V.: Strategic challenges of the 21 st century to the society and economy of Ukraine. In: Innovative and technological development of the economy. Kyiv (2007)

10. Filippenko, A.: Global forms of economic development: history and modernity. Kyiv (2007)

11. Levitt, T.: The Globalization of Markets. Harward Business Review. http://www.lapres.net/levit.pdf (1983). Accessed 21 Nov 2018

12. Al-Rodhan, N.R.F.: Definitions of Globalization: Ambassador Gérard Stoudmann. A Comprehensive Overview and a Proposed Definition. The International Relation and Security Network, Zurich (2006)

13. Fischer, S.: Globalization and Its Challenges. American Economic Review. 93(2), 1-30 (2003). doi: $10.1257 / 000282803321946750$

14. Bauman, Z.: Globalization. Consequences for the person and society. Moskow (2004)

15. Kay, S.: Globalization, Power, and Security. Security Dialogue. 35(1), 9-25 (2004). doi:10.1177/0967010604042533

16. Reich, S.: What is globalization? Four Possible Answers. NBRR Working Paper Series. 261 (1998)

17. Thomas, C., Wilkin, P. (eds.): Globalization and the South. Palgrave Macmillan, London (1997).

18. Clark, I.: Globalization and the Theory of International Relations. Review of International Studies, 24(4), 479-498 (1998)

19. Working for a Better Globalization, given by the Managing Director of the IMF at the United States Conference of Catholic Bishops in Washington D.C. http://www.imf.org/external/np/speeches/2002/0128 02.htm. (2002). Accessed 15 Nov 2018

20. KOF-globalization-index 2017. https://www.kof.ethz.ch/en/news-andevents/media/press-releases/2017/04/kofglobalization-index-2017.html (2017). Accessed 13 Nov 2018
21. The Economist Intelligence Unit's Democracy Index. https://infographics.economist.com/2018/Democrac yIndex (2018). Accessed 18 Nov 2018

22. Europe's Economic Outlook in Sxi Charts. International Monetary Fund. https://www.imf.org/en/News/Articles/2018/11/07/n a181107-europe-economic-outlook-in-six-charts. (2018). Accessed 22 Nov 2018

23. Indicators. The World Bank http://www.worldbank.org/en/search?q=Indicators (2018). Accessed 28 Nov 2018

24. Kasych, A., Vochozka, N.: Conceptual provisions of development of Ukrainian national innovation system. Scientific bulletin Polesie. 2(10), 2, 16-23 (2017)

25. Global Migration. Migration data portal. https://migrationdataportal.org/data?i=stock_abs_\&t $=2017$ (2018). Accessed 28 Dec 2018

26. Kasych, A., Breus, S., Khaustova, Ye.: Economic security of institutions of higher education from the perspective of international competition. Baltic Journal of Economic Studies, 4(5), 1-9 (2018). doi:10.30525/2256-0742/2018-4-5-1-9 